\title{
Enterprise Unions: Panacea for Industrial Harmony in Malaysia?
}

PETER WAD

\begin{abstract}
As industrialization has been conceived by the Malaysian government as a strategic means for accomplishing the development policy of national stability and unity, poverty eradication, ethno-economic restructuring and finally for achieving the status of a developed country by the year 2020, industrial peace has been accorded a high priority. During the 1980s and 1990s industrial strife declined to very low levels, after an elaborate system for conciliation and arbitration had been put in place in the 1960s. But industrial peace did not equate with industrial harmony and productive behaviour. Adopting a policy of in-house unionism in the early 1980s, the Malaysian government tried out a new mechanism for securing cooperation and consensus at the enterprise level, focusing on the new Malay workforce in the modern sectors and bypassing the traditional trade unions, structured on industrial, occupational and trade boundaries.

Based on three case stories from the metal industry, this article demonstrates that enterprise unions are not by nature docile, managementcontrolled trade unions in a Malaysian context. A certain dynamic of enterprise industrial relations is delineated and explained by union democracy and independence on the one hand and employers' policies and practices in terms of personnel and industrial relations management on the other. The labour laws and the authorities provide a framework and mechanisms for conflict interpretation and resolution, but a statist explanation of Malaysian industrial relations at the enterprise level is insufficient. The management-labour relationship has to be taken to the forefront of the analysis, which falsifies some of the myths surrounding enterprise unions in Malaysia. ${ }^{1}$
\end{abstract}

\section{In Search of Industrial Harmony}

Industrial strife predominated in Malaysian industrial relations during the late colonial years of the 1940s, but it was more or less suspended during civil war and the emergency of 1948-60. In the 
formative years of Malaysia (established 1963) and the confrontation with Indonesia in 1963-65, industrial militancy returned, with more than 300,000 workdays lost every year in the period 1962-64 and over 100,000 in the following years 1965-68 (Jomo \& Todd 1994: table 2.16). The lowest level of industrial conflict was recorded in 1970 with less than 2,000 workdays lost, but then industrial conflicts rose again to a peak during the economic recession of 1974-76. From the mid-1970s industrial strife evaporated steadily, with a minor peak of industrial action during the economic crisis of 1985 and an exceptional single big strike in 1990 in the plantation sector with the loss of nearly 300,000 workdays. During the 1990s the amount of industrial action returned to the low level of the 1980s and even declined further from 23,500 workdays lost in 1991 down to 2,500 in 1996 (pers. comm. Ministry of Human Resources (MHR) 1997). In short, Malaysia has achieved stable industrial peace during the last 25 years, a period of tremendous economic, political, social and cultural transformations.

Achieving industrial peace has been a major concern for Malaysian governments during the post-colonial time and especially since racial riots in 1969 made the government reformulate the overall development policy. An interventionist policy was adopted in 1971, based on the ideology of nation-building and political unity (Rukunegara), the eradication of poverty and the ethno-economic restructuring of the Malaysian society, upgrading the Malay community in terms of capital, employment and education in the modern sectors (New Economic Policy, NEP, 1971-90).

The general strategy emphasized rapid economic growth, industrialization and employment generation, and the more specific strategies included positive discrimination towards Malays (quotas for education and employment), establishment of trust funds and stateowned enterprises, and export-oriented industrialization (e.g. Export Processing Zones; export incentives; foreign direct investments). Political and economic stability became a mantra in order to attract transnational companies and investments, and by implication, industrial peace was perceived as crucial for successful implementation of the NEP. The call for industrial harmony was reiterated when the National Labour Policy (NLP) was announced in 1992 after the adoption of the National Development Policy (NDP), successor to the NEP and the first step towards the transformation of Malaysia 
into a developed country by the year 2020 in accordance with the long-term strategy ('Vision 2020') for the period 1991-2020.

In practice Malaysian governments have steadily narrowed the space for legal industrial action through labour legislation (e.g. in 1959, 1967, 1980), establishing an industrial relations system based on conflict resolution through conciliation and arbitration within a state-dominated corporatist system consisting of the authorities (Ministry of Human Resources, Industrial Court, Labour Court), employers' associations and trade unions.

This very thinly masked net for bringing industrial conflicts into a conciliation and arbitration system has been developed since the mid1960s. Compulsory arbitration became introduced by decree after the mass strikes in 1964 and then institutionalized via amendments to the labour laws in 1967 after the end of the confrontation with Indonesia. More restrictions were added after a wildcat strike by employees of the Malaysian Airlines System (MAS) in 1979, which resulted in international sympathy actions after the Malaysian government had jailed trade unionists. In the end the government abolished the trade union of airline employees, allowing one trade union for foreign airline employees and one in-house union for MAS employees, before they finally tightened the Industrial Relations Act in 1980.

This was the last major revision of the Industrial Relations Act. Today, legal and legitimate strikes and lockouts are very difficult to instigate because they presume either administrative mistakes or political acceptance of the strike - which anyway happened in 1990 in the plantation sector. Moreover, legal strikes are only available for trade unions. Strikes by non-unionized employees are by definition illegal and thereby a matter of police prosecution. However, wildcat strikes take place among both non-unionized and unionized workers. For unionized workers, wildcat strikes have serious implications, providing legal justifications for employers to sack the persons involved and for the authorities to close down the enterprise union or worksite committee (earlier the whole union would be deregistered if a union worksite committee went on illegal strike and the union did not stop it immediately). Finally, collective agreements (CAs), registered and enforced by the Industrial Court, normally provide guidelines for settling industrial dispute. Although union membership is limited to around $10 \%$ of the workforce and probably with the same amount of employees being covered by collective 
agreements (some union members do not have CAs, while employees are covered by the $\mathrm{CA}$ of the company whether they are union members or not), more than $60 \%$ of all industrial disputes referred to the authorities concern collective bargaining and contractual terms of collective agreements and other service contracts (Yong 1996: 206, table 8-10). The outcome of the compulsory conciliation and arbitration system is that at least $75 \%$ of all cases brought into the state-corporate industrial relations system were solved through conciliation in 1991-92 (Yong 1996: 205, table 8-7), more than $90 \%$ in 1994, while the target of the Ministry is to achieve zero cases of arbitration (pers. comm. 1995).

In sum, the Malaysian state has achieved industrial peace through labour legislation, administrative, conciliation and arbitration mechanisms and an overall development policy for rapid economic growth and ethno-economic restructuring. However, industrial peace, understood as lack of industrial actions like strikes and lockouts, is identical neither with industrial harmony, i.e. cooperation based on consensus about objectives and means at the enterprise level (Balan 1995), nor with rising productivity. Instead, 'peace' may come from a culture of silence, based on authoritarianism and suppression, and this may again generate workplace resistance and unproductive behaviour and inspire to more subtle means of struggle: legal and open actions (e.g. refusing overtime work beyond law and collective agreement), covert resistance (e.g. go-slow, sabotage), or public in-house (picketing) or out-house (state conciliation and arbitration) actions.

In order to establish a framework for industrial harmony, the government at first tried social corporativism. In 1975 a tripartite consensus formula for industrial cooperation was reached between the government, the labour centre (Malaysian Trades Union Congress, MTUC) and the employers' federation (Malayan Council of Employers Federation, MCEF), named the 'Code of Conduct for Industrial Harmony'. This tripartism did not last long, and more tense relations evolved again between trade unions and the government, reaching a peak around the MAS-conflict of 1979-80.

Since the early 1980s the government turned to another strategy by applying a new policy of organizational transformation of the trade union movement, promoting enterprise unionism as an alternative to the dominant structure of national industrial unions. 
This article aims to analyse the Malaysian policy of enterprise unionism within the political quest for industrial stability and harmony, questioning the belief that enterprise unions act more peacefully and cooperatively than other types of trade unions in Malaysia. By enterprise union I mean trade unions that organize employees within the same enterprise (plant, establishment, company corporation), while industrial unions unionize employees within a particular industry (or sub-industry), and national unions are trade unions that unionize members within a particular trade, occupation or industry but cover employees within the nation (in Malaysia to be understood as the federation (Peninsular Malaysia) or the confederation (Peninsular Malaysia, Sabah and Sarawak).

At first the article describes the Malaysian policy of enterprise unionism in terms of public discourse and political-administrative practice. In order to prove that enterprise unions are not docile and loyal organizations by nature, several cases of militant enterprise unions are presented. Finally, the dynamics of and conditions for enterprise union militancy are discussed in terms of trade union democracy and the employers' personnel and industrial relations policy. The article concludes that enterprise unions are not a panacea for industrial harmony. On the contrary, the belief by employers and authorities that enterprise unions are weak and easily manipulated might backfire and create very tense industrial relations at the enterprise level - tensions which are very difficult to settle with or without external intervention.

The empirical evidence on enterprise unions was collected during a research project, financed by the Danish Council for Development Research and institutionally affiliated to the Department for Intercultural Communication and Management. The research project included field research with interviews of key stakeholders of the Malaysian industrial relations system and more than 20 trade union case studies in Peninsular Malaysia 1995-96 (see Wad 1996a, 1996b, 1997a, 1997b; additional and earlier writings are found in Wad 1988; Wad \& Jomo 1994). For my field research in Malaysia in 1995 and 1996, I obtained a research permit from the Economic Planning Unit of the Prime Minister's Office and I became attached to the Institute of Advanced Studies, University of Malaya. The Malaysian authorities in no way restricted my research, but a few employers refused to cooperate, including prohibiting me from meeting officers of the 
enterprise union. Persons and companies are accorded anonymity where I use information obtained directly and not available to the public, except where they have agreed to be identified by name or position. Finally, it needs to be underlined that the interviews are edited for reading purposes.

\section{The Malaysian Policy of Enterprise Unionism}

The 'in-house union' policy was launched in 1983 by Dr. Mahathir Mohamed, the Prime Minister since 1981. His advocacy of enterprise unionism followed the announcement of the 'Look East' policy in 1982, whereby he wanted to turn Malaysia away from a Western orientation of development and instead to take the East as a development model, emphasizing the successful economic development of Japan and, to a lesser degree, South Korea.

In Mahathir's controversial book The Malay Dilemma (published in Singapore in 1970, but banned in Malaysia until 1981 when he took over as Prime Minister) he did not completely reject the notion of trade unionism in relation to the pro-Malay policy, but he found trade unions irrelevant in the reshuffling of the Malaysian society. At that time Mahathir probably saw no alternative to either the British pattern of unionism or state protection making trade unions obsolete. With the expansion of Malay employment in secondary and tertiary sectors, Mahathir was looking for an alternative, which facilitated the NEP strategy of ethno-economic restructuring with growth without making the Malaysian labour institutions obsolete. Japan turned out to be a relevant model for development:

Our Look East policy is directed not so much at investment from Japan but at acquiring the kind of policies, systems and work ethics that the Japanese have. We see the Japanese have made headway while the West ... appears to be regressing. So in order for Malaysia to progress, we have to learn from the better example. This is why we now want to Look East where before we were looking West (Far Eastern Economic Review, 11.6.1982).

In 1983 he argued that Malaysia had to change the core organizational component of its industrial relations system to fit the development requirements of Malaysia: 
There is a need for Malaysia ... to look into a new concept like inhouse unions that have been used successfully by the Japanese 'who have easily beaten the West' which practises the old system of trade unionism (New Straits Times, 6.3.1983).

Besides advocating in-house unions because they were part of the successful Japanese system, Mahathir also legitimized enterprise unionism by emphasizing the particular situation of new industries and companies to be established in Malaysia in order to secure development:

Some of our companies ... have just been set up and are coming up but if forced to pay the same benefits as the more successful ones will definitely not succeed. Hence ... it would be more meaningful for these firms, especially the new ones, to have in-house unions which have proved to be a big success in Japan . . . by having a union within a firm, the union could negotiate with the management concerned, while taking into consideration the various circumstances. And with workers totally involved in the company, which would result in increased productivity and higher profits, all sectors would benefit, including the Government through revenue. It would therefore be more meaningful . . . for the thousands of workers in firms and not represented by unions to have in-house unions (New Straits Times, 6.3.1983).

In the eyes of the government enterprise, unionism appeared as a triple-win formula, benefiting employers, employees and the state. Moreover, it fits with the needs of workers in non-unionized enterprises, industries and sectors and especially in newly established companies. Argued that way, 'latecomer' industrialization with infant industries and expanding Malay employment in the modern sectors called for enterprise unionism without substituting industry-based unions in the old industries with Indian and Chinese labour.

During a public debate on the necessity of amending the Trade Union Act under the economic recession of the mid-1980s, the authorities argued that enterprise unions were particularly relevant in bigger companies where their membership can be large enough to protect against exploitation. National unions would still be appropriate and effective in small and medium-size companies and within the primary sector (the plantations) where they are 'very established and efficient' (New Straits Times, 31.7.1987, quoted in Latiff 1988: 50). 
Simultaneously, a dispute between a national union and a newly formed in-house union in the banking industry disclosed that enterprise unions were non-existent in a legal sense, because the concept was not used or defined in the labour laws. After a Supreme Court award in 1988, won by the National Union of Bank Officers and dissolving an in-house union within the jurisdiction of the national union, the government immediately changed the Trade Union Act legalizing enterprise unions. Hereafter, an enterprise union was legally defined as a trade union of employees within a particular establishment, i.e. 'any place of business or employment belonging to an employer and includes any division or branch thereof' (Trade Union Act 1959 and Regulations, 1995, Part I, section 2).

The rationale for promoting and institutionalizing enterprise unions was very much the same in 1995 as it was in 1983 and 1987:

In the early eighties, the Government announced its policy of encouraging the formation of in-house unions. This in-house union concept which followed on the heels of the Government's Look East policy was intended to spur worker loyalty to enterprise and enhance closer employer-employee ties for the well-being of the company and the nation as a whole. In-house unions are inevitably better acquainted with and committed to the objectives and operation of the establishment in which the members work. This would facilitate smoother negotiations and collective bargaining between labour and management. The tendency for the national unions to exert pressure in securing uniform wage rates and other conditions of employment may produce a negative effect on the continued growth and viability of small and medium sized or newly established industries (Ministry of Human Resources, mimeo, 1995: 5).

The Ministry argued that in-house unions facilitate industrial harmony between the employer and the employees to the well-being of all concerned parties (the employer, the employees and the society). The behaviour of the employees and the union will be more responsible as the in-house union becomes more loyal to and gains better knowledge about the company's situation and objectives. Moreover, a negative sanction operates as well: contrary to national union officers, in-house union leaders work in the company and will lose their jobs if the company goes bankrupt. In sum, the government takes a positive stance towards the concept of in-house unions 
relative to other types of unions, promoting the idea as expressed by an officer of the Ministry of Human Resources:

We encourage in-house unions because they know better the requirements of the workers and the company. The workers will not be represented by aliens to the company (interview 1995).

Still, the Ministry of Human Resources recognizes that industrial conflicts are endemic to industrial relations:

Industrial grievances are common whether or not [there are] in-house unions, national unions or no unions. Due to the overall structure of industrial relations there are bound to be conflicts. But in-house union leaders will be more responsible. Capable leaders will also continue in office (Ministry of Human Resources, mimeo, 1995).

Regarding policy implementation, the Ministry of Human Resources takes a pragmatic approach to most issues, meaning that the officers try to delegate most cases to the parties involved (the national labour centres, the MTUC and the MLO (Malaysian Labour Organization) (1989-96), and the national association of employers, the MEF). The Ministry advises employees who want to set up in-house unions to visit the MTUC or MLO in order to get advice and support. It wants to intervene as little as possible and to refrain from forcing regulations upon managers, unions and employees.

The promotion of in-house unions follows this norm of pragmatism: 'We encourage workers to form in-house unions, but we do not want to force or phase out national unions. It is up to the workers to decide (Interview 1995).' The Ministry is aware of certain weaknesses of enterprise unions, and especially two aspects are highlighted: First, in-house unions are small and financially fragile; second, during negotiations workers come face to face with their own bosses and may feel subordinated, impeding negotiations between equals as in the case of national union leaders and managers. Therefore, it is argued, the Ministry ought to and does take more care of in-house unions compared to national unions. In fact, the Ministry considers how the weaknesses of the in-house unions could be mitigated, although it admits that it does not know very much about what is going on 'out there' (interview 1995). The Ministry recognizes that in-house unions need more training and education, and the Ministry is presently looking into the matter (interview 1995). The confinement of in- 
house unions to establishments within particular industries, trades or occupations is also under review.

In sum, the policy of enterprise unionism looks like an innovative approach (organizational restructuring) for achieving industrial harmony. Relying on ideological and administrative means, and appealing especially to the new Malay workforce in bigger companies, it deviates from the traditional Malaysian labour policy of tight labour laws to facilitate industrial peace. The policy did not explicitly aim for the extermination of the existing national unions, but focuses on the (unorganized) new and upcoming workplaces and workforce. Moreover, the government assumes that enterprise unions provide for an enterprise perspective and loyalty which assist enterprise-based cooperation and collective bargaining, improving productivity and reducing the risk of industrial tension turning into work stoppages. It is not only employers and workers who would win by solving the problems in-house; the state would gain, too, in terms of increased revenues. The concept of enterprise unionism promised a triple win-win-win scenario of industrial harmony, but does it meet these expectations in practice?

This interpretation of the government's in-house union policy is contested, not least by the MTUC. Criticizing the policy of enterprise unionism of the 1980s, the late President of the MTUC, P.P. Narayanan, held that the government got the 'enterprise union' concept wrong, forgetting the lessons of the 1950s when in-house unions were infiltrated by outsiders (anti-national elements, irresponsible politicians) and workers became unmanageable for investors as well as for authorities, forcing the government to rely on the sober and stable leadership of national unions (Latiff 1988: 54). However, this interpretation of Malaysian trade union history does not fit the facts because much strike activity was initiated by national unions against employers resisting unionization of their company (Jomo \& Todd 1994: 93-96). However, it is correct that Malaysian enterprise unionism predates the 'Look East' policy, even back to the turbulent years of late colonialism, but in-house unionism was not promoted by the government before the 1980s.

The present General Secretary of the MTUC, G. Rajasekaran, drives home another argument, by saying that the government creates a lot of obstacles for the national unions and their effort to 
unionize employees, implying that at least in practice it has not been possible to establish a new national union since the inception of the enterprise union policy in the early 1980s, and that there is no free choice between joining national unions and enterprise unions, because in-house unions are treated preferentially by the Ministry of Human Resources and the government (interview 1997). The General Secretary is right when we talk about the component electronics industry, and when he talks about national unions being obstructed by the authorities when they try to unionize companies. But in other cases do the authorities, the Industrial Court and the civil courts act in accordance with the claims of the national unions? The picture of Malaysian industrial relations is not black and white regarding the relationship between the trade unions and the government. Focusing so much on the state's policy and practice, the policies and practices of the employers are pushed into the background or deliberately overlooked. And it is indeed the relationship between the employers and the trade unions which needs to be placed in the limelight if we want to understand what is going on (Wad 1997b).

\section{Enterprise Unions and Industrial Militancy in Malaysia}

Based on the pre-1980s experiences, the Malaysian government might have been right in their judgement that enterprise unions are more docile and collaborative than the national unions. No enterprise union is publicly known for its militancy before 1980. In fact, it seems that enterprise unions turned militant after the announcement of the Look East policy and the endorsement of the policy of enterprise unionism! Two examples:

- The employees of an old rubber manufacturing company took control of the management-dependent in-house union in the early 1980 s and forced the management to recognize the union and accept collective bargaining. The ongoing management-labour conflicts and the declining demand for manufactured rubber products caused mass retrenchment in 1983, suspending production for several months. The Hong Kong Chinese-owned factory was only saved by being acquired by a domestic Chinese company, which brought in new capital, technology and management. The new management also took a new industrial relations approach, recognizing the legitimacy of the in-house union, making 
company performance more transparent and establishing bargaining procedures on productivity-based wage schemes.

- In another large rubber product manufacturing company, an in-house union was established in 1968 after the worksite committee of the national union had been deregistered during a wildcat strike. The management was supportive of the formation of a new union, being used to collective bargaining at the enterprise level. Employees controlled the enterprise union during the 1970s, and a house was bought for use as a union office. When tensions increased between management and labour during the early 1980s due to the recession and retrenchment, the union leadership used controversial actions during collective bargaining. The management dismissed them for taking illegal action, but the Industrial Court ruled in favour of the union leaders, forcing the company to reinstate them. However, during the next round of retrenchment the union leaders volunteered for retrenchment, feeling that a new batch of leaders had to take over after the situation of the company had changed radically. In order to carry the decision through, one of the former leaders stayed as paid union officer with the objective to train and assist the new, young and inexperienced union leaders. The strategy succeeded, and the union leadership has confidently handled union affairs ever since, including tough negotiations on more flexible working hours demanded by management since 1996.

Are these two cases from the rubber manufacturing industry exceptions from a normal pattern of docile enterprise unions? In order to understand the dynamics of enterprise unions, we shall take a look at some in-house unions in another industry, namely the metal industry (here delimited to the steel and metal products industries).

The steel and metal product industries are primarily home market, non-Malaysian, resource-based industries, compared to the rubber product industry which is a Malaysian, resource-based and exportoriented industry. The industries are within the jurisdiction of a national industrial union, the Metal Industry Employees' Union (MIEU), which operates mostly within the metal product industry. In the integrated steel mill industry it has unionized two (Antara Steel, AM Steel) out of four steel mills, counting around 700-900 members out of a total union membership of over 12,000 members, or less than $8 \%$ of its total membership. The two steel mills outside 
the domain of the national union are the Malayawata Steel Mill, with an in-house union, and the Perwaja Steel Mill, without any trade union. The Perwaja Steel Mill, a state-owned company, is presently being restructured because it is de facto bankrupt due to a number of factors: mismanagement, corruption, the failed transfer of Japanese steel technology, the wrong geographical location, etc.

In the following section three in-house union case stories are presented. These in-house unions changed from a more cooperative, management-oriented policy to a more militant, member-based policy. In a metal product factory (company A), a management-initiated inhouse union turned into a militant union fighting for better terms of employment. In an integrated steel mill (company B) a cooperative enterprise union went through leadership changes and fought the management in order to improve wages and working conditions, ending with picketing, retrenchment and the return of former leaders. Finally, the radicalism of union leaders in another steel mill (company C), ended with the fall of the enterprise union and the return of the national union, which became recognized by the management.

\section{Company A}

The company began operations in 1958, manufacturing plain cans and boxes for biscuits, cooking oil and kerosene (Kuala Lumpur Stock Exchange 1995). Five years later it started producing lithographed tin cans and boxes. In the mid-1980s, the company diversified into carton manufacturing and services for the packaging industry, expanded into beer and beverage cans manufacturing for home and world markets, and acquired a plastic-bottle manufacturing business. In 1989 it began producing two-piece aluminium beverage cans for domestic and export markets. In the $1990 \mathrm{~s}$ it expanded and upgraded manufacturing technology for colour printing and aluminium-can making. The turnover of the company has increased steadily in spite of fluctuating macro-economic trends.

The company is part of a business group of ten companies controlled by a domestic Chinese family. It has been a public listed company since 1984, and the family control is centred in a holding company, formed in 1982. This control is now in question owing to a family feud, dating back to the restructuring of the company prior to public listing (Far Eastern Economic Review, 15.2.1996). The two factions of the family are each headed by sons of the founding father and his first wife. One son, being Executive Director and the 
mastermind of the expansion of the company into the leading position of the packaging industry, is trusted by most family members. The other son is Managing Director, contending that the shares be sold en bloc in order to secure a higher price (by selling a controlling share), and in the same stroke precluding the possibility that the other faction might assume control of the company.

The management-initiated formation of the in-house union in the mid-1980s came about when employees attempted to join the national union (MIEU). The management became aware of this and wanted to prohibit the company workforce from being controlled by an external trade union. The management used all means available to keep the union out. Realizing that it was impossible, the management persuaded some employees, primarily supervisors and clerical staff, to start an in-house union, assuming that a national union is very strong while an in-house union is weak and manageable. The in-house union became quickly registered by the Registrar of the Trade Unions (RTU) and immediately recognized by the management. In the view of the present union leadership, the enterprise union was born in the following way:

What happened was that in 1984 a group of workers from this company had the intention to form a union. They got help from a national union which is called MIEU, Metal Industry Employees' Union. These people helped the group of workers here to join the national union. That is what happened. When that happened - when the workers tried to form a union - the management came to know about it. They were against it. They found ways and means to stop it happening. In 1985 the management decided that instead of having a national union here they intended to have an in-house union. What they did was to quickly call a group of workers who were on their side and pick them up as a pro tem committee and these people formed the in-house union. They quickly wrote in all the forms and everything to the RTU, the Registrar of the Trade Unions under the government, who immediately approved the formation of the inhouse union. In 1985 we formed an in-house union and had the first Annual General Meeting (AGM) at the beginning of 1986. At that time there were 250-300 members (interview 1995).

The Executive Secretary of the MIEU describes the means used by the management and the RTU to overcome the claim of the national union: 
IP (interviewee): The workers joined us actually. When the membership check was carried out by the RTU the company went and applied for an in-house union and they even told us that they had already recognized the union. There was again the same dispute about who made the application first. We told the Registrar that he could not register the other union before our matter was resolved. Resolved in the sense that when they carried out the ballot we had $44 \%$. There again we are not satisfied, because this company has within their group another factory engineering products, making machine tools, another one making paper cartons, all different, separate companies. But when they sent the papers on the membership check they took all of them together. If they had sent only the can factory we would have had a majority.

PW (Peter Wad): How can they do this when they are separate factories?

IP: The government does not check the problem, you see. They keep it confidential. They don't tell us. They come, collect our records and check our records. But as far as the company is concerned, whatever they receive they just accept. We said, please check on that. We wrote to the company and said $44 \%$ voted for the union. The company said that they would not recognize it. Next day they recognized this [inhouse] union immediately because there were very good connections between [the company] and the MCA, the Chinese party which is a coalition partner in the ruling government. They are very close with the Minister. It is our view that the Minister intervened.

PW: Whom could they get to stand for the in-house union? The supervisors?

$I P$ : Yes, the supervisors. They had a very small membership. As I said, at that particular company we had much more than 50\%. Then the moment our claim was rejected when they registered the union and the employer immediately recognized the union, after that we disputed, we complained, the procedure was not proper, the Minister just dragged his feet. They even concluded a collective agreement very quickly and registered it. This happened to us.

$P W$ : Did you lose contact with this factory or do you still keep in touch with these former members? 
IP: Sometimes they came back for advice. Later on they said, well the in-house union is there, we will go and join in and try to take the leadership, and put our own independent people there. So we said all right, go ahead and give them some support. They set off, and this is still going on (interview 1995).

Some years later, a group of rank-and-file members, primarily production workers, changed the leadership into the present one, composed entirely of technical, transport and production people, with no supervisors or clerks in the executive committee except for one woman from a subsidiary factory, covered by the union. In the words of the present leader of the enterprise union:

What happened was that the old guys were there from 1986. I would say the union was not active in terms of getting benefits for the workers. Those guys were only there to run the union and it went on like that. There were no changes. They did not really look into what the needs of the workers were. Then came a group that thought that they would be better off by giving so many benefits. What happened was that they threw the old guys out and they took over. That was in 1989. Immediately when the new guys were in, in the space of three to four months', we got affiliated to the MLO [Malaysian Labour Organization]. When we got affiliated to them, we got all the help they could give us, because in terms of knowledge to run the union, these new guys were very inexperienced. When we got affiliated to them they helped us with so many things, giving us information, they had their own library, conducted courses for us, and all this. After that we came up all the way (interview 1995).

Although the management was unhappy with the new independent union leadership, they never tried to dismiss union officials. Several supervisors and clerical officers resigned from the union. Only recently, the union came to learn that some supervisors cancelled their membership after being threatened by the management, but they returned after the union intervened on their behalf.

The in-house union joined the MLO. Being formed in 1989 as a splinter labour centre and in dire need of affiliates compared to the MTUC (to which the MIEU is affiliated), the MLO contacted many enterprise unions to mobilize support. The MLO assisted the inhouse unions that were affiliating, including the union of company 
A, in preparation and negotiation techniques of collective bargaining, training members of the executive committee. The first collective bargaining after the breakaway from management control covering the CA-period 1992-94 quickly deadlocked and was referred to the Industrial Court by the Minister of Human Resources after conciliation by the labour authorities.

During this period of collective bargaining, the management barred the whole executive committee in the factory when the union leaders held an emergency meeting at the union office inside the plant, after the management refused to meet the demands of the union. The union officials had to call for help, and the police arrived and took the union leaders to the police station where they reported the incident. Then, the union leadership decided to stage a picket in front of the factory after working hours. When the management tried to prevent this by parking lorries at the nearest side of the street, the workers moved the picket across the road and into the shadow of some large trees. Then management had the trees cut. The next day workers prevented the management from parking the lorries blocking the picket. They picketed for five days, calling on passing drivers to sound their horns in sympathy, which they did. Newspapers also told the story of the industrial conflict. Finally the Industrial Court ruled in favour of the union with a $10 \%$ wage increase across the board plus other benefits, backdated for more than a year. The union encouraged the members to donate $10 \%$ of the arrears to the union, and the union itself donated RM5000 to the MLO in appreciation of its support.

After this confrontation, the management changed its attitude for a while. Union officials were allowed to conduct union affairs in the union office, located in the factory, but it was voluntary and took place outside working hours. The union leaders felt that they had proved that an in-house union has to be and can be a strong union. The power struggle went on, however. During the new round of collective bargaining for the 1995-97 period, the management again tightened the surveillance of the union (e.g. checking the union office and their presence). Now the union leaders just tell the management that they have to do the work during working hours because the building is closed at 6 p.m.

The CA negotiation in 1995-96 again reached deadlock, and the case was sent for conciliation to the Department of Industrial 
Relations of the Ministry of Human Resources. This time a compromise was achieved before the case was sent for arbitration (or, in theory, industrial action). The company would only give a $5 \%$ wage increase (while the union wanted more than $10 \%$ ). The compromise was $8-10 \%$ wage adjustment (depending on the wage level) plus two months' bonus (the normal level at present). However, the CA was not immediately endorsed by the Industrial Court because two paragraphs were not in accordance with the labour laws. The management secured anyway for the employees to receive back payment of wages for the period before the court settlement.

The union has unsuccessfully tried to organize two neighbouring plants belonging to the business group but the RTU prevented them from unionizing the aluminium-box manufacturing plant, arguing that this industry was outside their jurisdiction. The National Union of Petroleum and Chemical Workers (NUPCW) tried to unionize the plastic-can factory. The management claimed that the employees had better terms now without a union and threatened that they would remove the benefits in the case of unionization. The no-union votes counted $65 \%$. Some of the union activists have since left due to harassment (interview 1996).

The Personnel Manager of company A, having experiences with one of the non-unionized factories of company, contends that it is much easier for management to run a company without a union. However, from the viewpoint of the personnel department, which has the objective to improve the conditions of the personnel (keeping them in the company in a full employment area), the anti-union stance is detrimental. The company has a very high turnover despite having recruited a new batch of Bangladeshi workers (keeping their passports due to unfinished procedure). In the personnel department they very much want an improved personnel policy, but top management is tough and anti-union for the time being.

In sum, the in-house union has jurisdiction over four: out of ten companies within the family business group (one of these companies, located far away from the core company, is closing down due to rationalization). Since the management-picked leadership was kicked out of office by the members, the management has fought the union but the union leadership responded with a more militant and tough policy and made the management understand that it had the power to withstand the pressure, thereby opening the way for 
mutual recognition and collective bargaining. One company in the business group is unionized by the national union, the MIEU. The explanation provided by the MIEU is that the MIEU was already present when the family acquired the company, and the General Manager, a younger son, takes a more cooperative approach to the union than his elder brothers in charge of company A (interview with the Executive Secretary of the MIEU, 1996).

\section{Company B}

The company was incorporated in 1961 and opened its steel mill in 1967, composed of a rolling mill, a blast furnace and an oxygen plant. The company was a joint venture between a state company (PERNAS) and a Japanese steel manufacturer (Nippon Steel) using Japanese technology and management skills for steel production during the startup. Before the world recession of 1974-75 the company expanded, constructing a second blast furnace, a second oxygen plant, a wire-rod mill and extended the existing rolling mill. With the state-led heavy industrialization programme for the 1980s, the state-controlled company expanded again, constructing a second rolling mill. Then the economic recession (in the steel industry 198487) forced the government to scale down its policy of heavy industrialization, since it faced excess capacity in the steel industry and lack of money for investment. After the economy picked up from 1987 the company enlarged its paid-up capital in 1990, doubling it to around RM135 million.

In 1992 the company commissioned a new steel-making plant (wire-rod mill using Swedish technology), which began operations in 1995. However, due to increased competition in the bar and wirerod market of the booming construction industry, profit and turnover started declining in 1993/94 and 1994/95 respectively. In 1996 the company decided to close the two old blast furnaces, and the subsidiary charcoal company that supplied the furnaces ceased operations. This rationalization implied retrenchment of more than 200 of the 1,435 employees of the company (December 1985) plus the employees of the charcoal subsidiary (company reports, Kuala Lumpur Stock Exchange 1996, interviews and documents 1995, 1996).

In the mid-1990s the company is still a state-controlled, limited company, rationalizing existing production systems (six plants in the same site and the charcoal subsidiary) and diversifying (into property and palm oil) in order to offset increased competition, 
increase the profit and reduce dependence on Japanese steel technology. Moreover, the closure of the blast furnaces will reduce negative environmental impact in the urban-industrial area, which is heading for high-technology.

An enterprise union was registered in 1970, immediately affiliating itself to the MTUC, then to the International Metalworkers' Federation (IMF) and the IMF-Malaysian Council. The employees at first wanted to become members of the national union of the metal industry (MIEU), but their claim was opposed by management and rejected by the Registrar of Trade Unions. Instead they formed an inhouse union, covering the steel company, but not the charcoal subsidiary.

For many years the management-union relationship wàs amicable and effective in terms of solving problems in-house. Only two or three cases went to the Industrial Court for settlement. During the recession of the 1980s the company refrained from forcing mass retrenchment while the union agreed to prolong existing collective agreements, abstaining from annual bonuses. However, when the economy picked up after 1987 and the company started making profit again, the union and employees expected that their pay and conditions would improve too. The management refused to meet these expectations and claims. The dissatisfaction among union members turned against the leadership of the union. When the General Secretary was promoted to Technical Officer after having worked ten years in the union office, he was challenged at the biannual general assembly (BGA) in 1991 by a rank-and-file candidate without union leadership experience at all, and he lost. At the next BGA (1993) the President lost too, ending a term of office that had begun way back in 1975. Meanwhile, the former General Secretary was persuaded to stand as a candidate for vice-presidency and was elected. The former President returned to presidency in 1994, when his predecessor left the company in frustration. In the BGA (1995), the old President abstained from candidacy while the Vice-President went for the presidency, and this time he lost. A new, more militant leadership had finally taken over the key leadership positions of the union.

Paralleling the radicalization of the union leadership, the new collective bargaining ran into deadlock. The collective agreement expired in 1994. When management would not fulfil the demands of the union, the union tried to bypass the management by addressing 
the board. When this failed they resorted to picketing for the first time during collective bargaining. The case was referred to the Industrial Court for arbitration after conciliation had failed. Before the award of the Industrial Court, the management announced mass retrenchment, due to rationalization of production. This retrenchment affected part of the union leadership (the President and several executive council members). Then, the General Secretary volunteered for redundancy, too, arguing that 'when the boys have to go, I must go with them'. Family responsibilities (for hospitalization) forced him to secure a lump sum which he could get from the redundancy benefits, and he had also been offered another job. When the management accepted, the top leaders of the militant group of workers left the company, paving the way for a comeback of the older leadership, and some of them returned, including the General Secretary of the 1980s. This veteran explained his perception of in-house unionism and his attitude to the management in the following way:

In those days, when the in-house union started, everybody was saying that it was a yellow union. In-house unions were regarded as yellow unions because when the companies face unions, you don't have the guts and negotiating power and all that. As I said earlier, the union managed to maintain its financial standing, and we established very close relationship with the management. We did not agree on everything but we got certain benefits from the management. For example, the check-off system whereby we deduct our dues. If we were to do it ourselves we would have a problem. A check-off system is very important. Without a check-off system the union would have a problem. Number two, sometimes we use the company cars going out to visit our members at hospital, personnel officers and all that. Therefore, we thank the management all these years. We created an understanding between the two parties: 'If you respect me, I respect you,' and that is the good relationship we have. Whenever we ask for any time off for coming over to the union office outside the factory, there is no problem. The management will let us go. What the management has let us understand all these years is that when you talk to a unionist, you are talking to a group of wise men, well trained and understanding, and that this is better than talking to a guy who knows nothing. If the union has problems, for example misunderstanding among the 
union members, the management will face the problem. They understand it and they have learned this lesson in all these years. If you have a strong union leadership, it is better than having a weak leadership, because then the company will have a problem. All the time they will have problems with the workers: if there are no leaders to guide the workers, then the management will have problems. This is the reason behind all these years of talking with the management, the personnel manager and all that because they understand us very well. Of course when it comes to wage negotiations and all that, then that depends on the profits of the company (interview 1995).

The management contended that the retrenchment exercise was neither a reprisal for the $C A$ conflict, nor targeted at the new leadership. However, the management preferred the former General Secretary to come back as President, which he was entitled to as he had contested the position during the last election. The management thought that he was a better choice because he not only looked after the interests of the workers but also took notice of the performance of the company.

In sum, the industrial relations between the management and the enterprise union changed for the worse when management deviated from the accepted dictum that 'we share the good times and the bad times'. The workers felt that they had made concessions during the bad times of the 1980s and had legitimate demands for improvements during the 1990s. When these did not materialize, the union membership radicalized and elected more militant leaders. However, implementing a tough and confrontational policy and fulfilling the promises were not easy. Two top unionists left the company voluntarily, and with plant closure the whole radical leadership fell apart, paving the way for a return of more pragmatic and collaborative leaders.

\section{Company C}

This company, a steel mill, is the core business of a huge Chinese family business group from Singapore. The family started manufacturing steel products in the 1930s and established a branch in Malaysia in the 1950s. In the late 1960s and 1970s the group began diversification into steel storage products and wire-rod milling, combined with foreign direct investment (Indonesia). In the early 
1980s the company installed a scrap iron meltshop to produce steel billets, integrating backwards. During the economic recession in the mid-1980s the company diversified into other sectors, covering assembling and marketing of motorcycles and vehicles, engineering, construction, property, trading, finance, agriculture, aquaculture and retailing. Due to increased production and diversification, the company's turnover tripled from 1984 to 1988 and so did its workforce (from 3,000 to 9,000 employees). Although it stagnated for the next couple of years, a new upturn took place during the 1990s, where the business group expanded every year, more than doubling turnover while the labour force increased to more than 14,500 . The steel mill expanded its workforce from $300-400$ in the mid-1980s to more than 500 ten years later, with a rolling mill capacity of 850,000 $\mathrm{m} / \mathrm{t}$ per year compared to 400,000 in 1982 (Kuala Lumpur Stock Exchange 1996; company report 1988).

In the mid-1990s the business group restructured into eight divisions and redesigned the management style from boss-centred to team-centred, based on a professional staff. The Managing Director, with no higher education, employed professional people as advisors and managed in line with his recipe of doing business: entering markets when they are down, buying when things are cheap. This is a risky business strategy and now the company goes for consolidation instead of diversification (interview 1996).

The in-house union of company $\mathrm{C}$ only existed for a short period, 1983-87. The union was initiated by the management when the MIEU knocked at the factory gate, and it dissolved due to militant action taken by the in-house union. A quarrel between management and union over Muslim holidays saw the demise of the in-house union in 1986. The union leaders wanted two days off for the whole workforce while the management would only allow one day in order to run the steel mill continuously. The union leadership then initiated a wildcat strike where workers downed tools. Having ignored the conciliation and arbitration procedures outlined by labour law, the strike was deemed illegal and the management took the opportunity to sack the whole leadership of the union -fourteen executive council members in all. The case was taken to the labour authorities and settled out of court with compensation paid by the company. The union became defunct but it was not deregistered. 
Because of a lot of workplace problems many employees felt that they needed a union. They turned to the MIEU for membership and support, and this time the MIEU managed both to unionize the workforce and to get the recognition of the management. The Executive Secretary of the MIEU explained the case:

The company had initially established that union because our union was there and they were worried that we would go in, so they themselves established a union with their own people. But over the years, with independent elections, you can't keep on influencing the members and keep the puppets of management there. It won't work too long. At some point the workers will decide and put in the people they want. When that happened the management normally found out that it was uncomfortable to work with them. So the workers joined us. The company had to deal with us (interview 1995).

The present MIEU worksite committee holds that the enterprise union could not solve the problems because it was on its own without any training and skills in union matters. However, things have not improved dramatically since the MIEU took over. Today the pay and working conditions are still unacceptable, and living conditions have even worsened during the last three years, not least because of the influx of foreign workers (interview 1996). The cost of living has gone up with rising prices for food, transport and housing, and the company does not provide good wages, benefits or welfare services. Working hours are long (48 hours per week), and sports facilities have been closed to provide land for new constructions. The working environment is very bad and hazardous, and the occupational health and safety committee makes only minor improvements. Young people do not stay long, and the company has a very high labour turnover. The local unionists feel that the company prospers without sharing the prosperity with its own workforce. The company discriminates against Malay and Indian workers while Chinese employees are well taken care of. The Personnel Manager is a puppet who has to take all issues to the General Manager. The relationship between management and the worksite committee is very bad, and they foresee that they will have to picket during the recently opened collective bargaining.

In short, the worksite unionists see the company as financially driven rather than people driven. More generally, they feel that the Malaysian working class remains poor while the country is boom- 
ing. The real situation is to be seen on the workfloor, they argue. You have to work seven days a week to survive, and not only the stipulated 48 hours. As one area committee member said: 'For the foreigners, it's a nice country, everything is beautiful. For the rich it is okay. For the poor working class it is hell' (interview 1996).

The union's perception of the company is diametrically opposite to the picture communicated by top management. As a sign of the company's excellence in product and service quality, a stylized lion's head has been chosen as the corporate symbol, representing a progressive philosophy and bold approach to business. With the mane symbolizing the rays of the sun, the basic source of life and energy in Chinese thinking, 'these elements combine to symbolize success, growth and a sharing commitment of social responsibility in a competitive environment'.

In sum, although the employees changed from the in-house union to the national union, industrial relations within the enterprise are still tense. In spite of changing company strategies, the personnel policy remained the same: a centralized and non-sharing policy subordinated the overall and centralized policy of money-making.

\section{The Dynamics of Enterprise Industrial Relations}

The government's discourse on in-house unionism emphasized the in-house perspective of employers and employees, supposing that it furthers company loyalty, common perceptions of goals and means, fair in-house sharing, and in-house problem-solving. The evidence presented shows that the practices of Malaysian enterprise unions do not fulfil the presumptions and implications of the government's policy of enterprise unionism. I do not contend that all enterprise unions are, have or will become militant unions, but I hold that Malaysian enterprise unions are not docile unions by nature, nor do they form a solid pillar for industrial harmony in Malaysia.

Why, then, do enterprise unions resort to public industrial action, using soft or even hard militant means of struggle? Why do they not resolve all disputes in-house in collaboration with management? Why is Malaysian enterprise unionism not the presumed panacea for industrial harmony?

The first question to be answered is whether or not enterprise union militancy is part of a certain dynamic of industrial relations at 
the enterprise level. Can we inductively delineate a pattern for the evolution of enterprise union militancy, based on a few cases?

In the case of company $\mathrm{A}$, a Chinese-managed corporation, the management initiated, with the assistance of the RTU, an enterprise union when the employees were in the process of being unionized by the national union. Although a collective agreement was signed, nothing changed for the better, and the union leadership was simply thrown out of office by rank-and-file opposition. By coincidence, the new union leadership was approached by a new labour centre which provided technical advice and training in support. Being able to mobilize members, who were predominantly women, and staging pickets and gaining publicity, the enterprise union managed to put pressure on the authorities and the management. They succeeded in becoming recognized by management as a serious player. When collective bargaining again deadlocked, followed by state-guided conciliation, disagreements were settled without resorting to compulsory arbitration.

In the case of the state-owned enterprise (company B), the enterprise union chose a strategy of collaboration for two decades, having established a kind of trade-off between company and union interests. During the economic recession of the 1980s, mutual cooperation prevented forced mass retrenchment in exchange for zero wage increases. When the economic recession turned into economic boom after 1987, the union naturally expected fairness and just distribution of the surplus. When this did not happen, union members became very annoyed and acted accordingly. At first they changed the leadership of the union, electing a new batch of more critical leaders. Next, the leaders pushed hard between and during collective negotiations, finally resorting to picketing, mass media publicity and state institutions for conciliation and arbitration.

In company $\mathrm{C}$, the management initiated an enterprise union, when the national union tried to organize the workforce. Later on, management failed to support claims deemed to be legitimate by the union leadership. The unexpected negative stance of management, fuelled by inter-cultural cleavages between a Chinese management and a Malay union leadership, provoked the union to stage a wildcat strike, followed by dismissals of union leaders and the withering of the union. The employees turned to the national union, which was now recognized by management. However, tensions between the 
management and the union locale continued, compelling local union leaders preparing for public action to increase pressure for improved pay and working conditions. In their view they were dealing with a very authoritarian, profit-minded employer who did not care whether the workers were enduring hellish working conditions or not.

In sum, the rise and fall of militant enterprise unions seem to follow a trajectory, whereby management, in response to membership recruitment by a national union, initiates, controls or accepts the formation of an enterprise union, raising workers' expectations concomitantly. When these expectations are not met by the management, members turn their back on management and the docile union leaders, elect new leaders or make the existing ones realize that they have to do something, and a period of militancy begins. Militancy may pay off and become part of union policy, or it may fail and fall with the radical union leadership, or it may escalate into illegal action and the dissolution of the union (through dismissals of leaders or deregistration). In other words, at the enterprise level, management seems to be unable to gain institutionalized control over the in-house union, as management control and rising dissatisfaction of union members generate counter-actions of various sorts, militant or not. However, enterprise union militancy does not necessarily continue as part of long-term union strategy.

Hence, the next question to answer is whether or not the dynamics, construed by way of induction, make sense in a theoretical perspective. Can they be explained or deduced by existing theories on enterprise unionism, or do they clearly falsify common theoretical thinking?

\section{Enterprise Union Independence, Democracy and Militancy}

The mainstream conception of enterprise unionism, delineating enterprise unions as one monolithic type of trade unions, has recently been criticized by Benson (1996), arguing for a more differentiated view on (Japanese) enterprise unions. Benson proposes that enterprise unions might be analysed in terms of structural and functional independence/dependence (of management). Structural independence is operationalized in terms of regular meetings among and between union officials and union members, and functional independence in terms of membership election of leaders, union-paid officials, and union policy, which 
does not lend full commitment to enterprise productivity (Benson 1996: 375-77). These two dimensions result in a typology of four types of unions:

- 'company unions' (low structural and functional independence);

- 'enterprise unions' (high structural, but low functional independence);

- 'oligarchic unions' (high functional, but low structural independence); and

- 'independent unions' (high structural and high functional independence).

In his survey of Japanese unions Benson found that $8 \%$ could be classified as independent unions, nearly $50 \%$ as company unions, and the rest split equally between enterprise and oligarchic unions. Moreover, Benson showed that independent unions were more militant than oligarchic unions and in general more strike-prone than other kinds of unions. However, in terms of a broader concept of militancy, including not only withdrawal of labour (strikes, goslows), but also overtime bans, protest meetings, posting and distribution of handbills, and the wearing of ribbons and armbands, independent unions do not differ from other types of unions (Benson 1996: 381-82).

Applying Benson's theory to Malaysian unions might not be relevant, since militancy in Malaysia has to be understood as a broad concept in order to make sense, because strikes for example are very rare, and go-slows are considered to be strikes and regulated by the same tough legislation. Besides, Benson's innovative theory needs to be reformulated due to conceptual confusion. Mixing union governance (election) with financial aspects (union wage payment) and policy aspects (productivity orientation) in one dimension (functional independence), and taking internal union democracy (communication among and between union leaders and members) for a separate dimension (structural independence), Benson's typology seems to be one of union governance (democracy) rather than a typology of union independence/dependence.

By delimiting union election of leaders to denounce structural democracy, and by preserving internal communications between union leaders and members for the concept of operational democracy, we can reformulate Benson's typology of union independence 
into a typology of union democracy, again providing for four types of unions:

- 'democratic unions' (B's independent unions);

- 'autocratic unions' (B's company unions);

- 'elitist unions' (B's enterprise unions); and

- 'consultative unions' (B's oligarchic unions).

The reinterpretation acknowledges that union leadership election covaries with union payment of officials' wages and with a nonproductivity-based union policy (Benson combined these three factors into one: operational independence, based on factor analysis).

Next, I propose to construct a new dimension of union independence, differentiated from union democracy. Union independence/dependence of management can be defined in terms of structural and operational aspects, too. By structural independence we mean that management staff (employees with management authority, including supervisors and foremen) are not part of union leadership, i.e. that the management of union affairs is not based or dependent on management personnel, making it structurally linked to the managerial hierarchy of the corporation. Operational independence means that the union leadership can function independent of management resources and services (union paid officials, office, communication, transports, etc). Again, we can outline four types of unions in terms of independence:

- 'independent unions' (high structural and high operational independence);

- 'dependent unions' (low structural and low operational independence);

- 'staff independent unions' (high on structural and low on operational independence); and

- 'resource independent unions' (high on operational but low on structural independence).

Finally, I prefer to cancel Benson's specific definition of enterprise unions, because it blurs the normal usage of the term. An enterprise union is to be understood as a trade union, organizing employees within the same enterprise (plant, establishment, company, corporation).

The relationship between enterprise union democracy, independence and militancy is a complicated problem area. Using our revised terminology, Benson's empirical material indicates that there is 
limited co-variation between union democracy and militancy (in the strong sense of strikes). Studies of enterprise unions in Mexico and India indicate that enterprise unions relative to national unions might (temporarily) be very militant (strike-prone), and that this militancy is conditioned by union democracy, either in terms of election of leaders by the enterprise workforce or by intensive communication between leaders and members (Roxborough 1984; Carillo 1995; Bhattacherjee 1987; Tuman 1996). Considering contradictory evidence on union performance or impact in terms of wages and work conditions in India and Malaysia, Edgreen (1990) argues that the core factor is union strength, and such strength might come from membership mobilization due to union democracy (for a review of enterprise union research, see Wad 1996a). Summing up, my hypotheses are, first, that management-labour conflicts with militant actions are more likely when the union is independent and democratic, and second, that union independence and union democracy are interdependent factors.

Reconsidering Malaysian unionism, enterprise unions are legal bodies defined, confined and empowered by the same labour laws which apply to other types of trade unions. This means that enterprise unions are legally defined as autonomous organizations vis-à-vis employers, that they consist of workmen (wage earners) and that they must not seek representation of management staff (employees with managerial, executive, confidential or security capacity [Ministry of Human Resources, 1995 Industrial Relations Act, section 9]). In sum, Malaysian unions are by law defined as structurally independent unions. In practice, if management takes control of the formation of the union, the union does not need to seek recognition from management, thereby avoiding that management will complain over the (by implication, illegal) unionization of managerial staff. The inclusion or exclusion of managerial staff is thereby a prerogative of management interpretation and decision. Supervisors and foremen are, as lower-ranked management staff, the most controversial category, sometimes included, sometimes excluded from the trade union of 'workmen' (but legally entitled to have their own union, if excluded from the union of workers). All in all, most national unions are structurally independent, while enterprise unions might often start as structurally and operationally dependent unions, 
being initiated by management and led by supervisors or executives with management support for union activities.

By law, trade union leaders must be elected by taking a secret ballot in accordance with the rules of the union (MHR 1995 Trade Union Act, section 40), but the law does not stipulate election procedures at decentralized levels of the trade union (e.g. worksite or area committees), which are within the remit of the leadership of the particular union. When the election of the executive committee of the trade union is legally bound to be carried out by secret ballot among the union membership, the enterprise union leadership must be elected by union members of the enterprise workforce. By implication and legally speaking, Malaysian trade union law secures structural democracy in enterprise unions. Moreover, management is legally obliged to abstain from intervening in internal trade union matters. Using legal methods, a management will not in the long run be able to determine the leadership of an enterprise union when rank-and-file employees form the majority of membership and mobilize around their own candidates.

Contextualized by such legal institutions, it is likely that militancy is explained by changing enterprise unions in terms of independence and governance. The militancy of the enterprise union of company $\mathrm{A}$ came after the union changed from an elitist union to a democratic union with the 'revolution' in 1989, transforming the union from a dependent union into a structural independent union, still dependent on management resources for operation, but seeking alternative resources from an external labour centre. One hypothesis could be that in order to sustain the policy of contested bargaining, the union needs to establish operational independence. In company $B$, the union began as and remained a democratic union, which demonstrated its capacity for leadership transformation in the 1990s. A small intermezzo took place in the 1980s, which disqualified management staff (supervisors) from holding leadership positions in the union. When the union turned to militancy, it cannot be explained by changes in union democracy or independence. It remained as a democratic and structurally independent union, lacking operational independence (although it had an external office in its own building, beside having an office at the factory site for daily activities). The switch to militancy followed a perceived deviation from a norm of reciprocity in management-labour 
relations. But the militant leaders did not take the policy through to victory, and the union returned to a policy of collaboration after the radical leaders left the company. The union appeared to be operationally dependent on the company, and although this fits with the old management style, it may not fit with the new and more aggressive, business-oriented management.

In company $\mathrm{C}$, the union turned to militancy on an ethnic issue, seemingly without prior transformation of its low operational independence. It was probably an elitist union where leaders did not secure broad and daily support for the enterprise union. Without having established operational democracy, the union withered after the wildcat strike and the sacking of the union leadership. Dissatisfied with pay and working conditions, members resigned to join the national union, which the management now recognized as representing the workforce. Still, without having achieved any significant improvements, the worksite committee of the national union is taking a tougher stance against the management, paving the way for militant action in future negotiations. How this is looked upon by the HQs of the national union is another matter. The employees have become part of an independent national industrial union, where a wildcat strike in company $\mathrm{C}$ can put the entire national union at risk.

In sum, union democracy and union independence do explain part of the story of enterprise union militancy, but union policy is also conditioned by management policy, power and ethno-cultural outlook.

\section{Management's Industrial Relations Policy}

The key dimensions of management's policy is whether it adheres to a policy of collective or individual contract negotiations, and whether it takes an authoritarian or cooperative attitude to management-labour relations. The traditional Western pattern of collective bargaining at company, industry or national level has been based on a management priority for collective cooperation, evolving through historical and militant struggles with large-scale strikes and lockouts. With the new ideology of human resource management, managers prefer individualized, cooperative relations, based on direct employee involvement, and bypassing union interventions or mediation. In developing countries, the traditional personnel policy has been based on individualistic and authoritarian management of labour, 
not least in small companies, owned and operated by family members, in particular Chinese families. Finally, authoritarian and collectivist approaches are found within societies where collectivism and authoritarianism are basic institutions (e.g. in ethnic Malay communities).

Latiff argues that management's labour policy is the decisive factor for the evolution of enterprise union into collaboration or militancy (Latiff 1988). It is my contention that the course of enterprise industrial relations is conditioned, but not solely determined, by the management's policy and practice, making militancy less likely with management adhering to cooperative and collective policies of enterprise industrial relations and personnel management.

The two managements of the Chinese-controlled and managed companies ( $A$ and $C$ ) stuck to authoritarian and individualistic policies. When confronted with the national union, they preferred to establish an in-house union, and succeeded. However, they did not change their management style and the union did not bring any improvements. This policy caused a rapid deterioration in the management-labour relationship, sparking off membership mobilization around a new and militant leadership in company $\mathrm{A}$, and an illegal wildcat strike and the fall of the union leadership in company C. While the enterprise union sustained its position in company A, the national union came back in company $C$. In no company did the management change the company's personnel policy or industrial relations approach, although they have adapted to changing relations of power (accepting a compromise before arbitration in company $\mathrm{A}$, and negotiation with a national union in company $\mathrm{C}$ ).

Both these companies changed from non-listed, private and personally (family) owned firms to public listed corporations, still with the family in firm control of shares and executive management positions. Both companies are market leaders within their fields, using state-of-the art technology, producing for domestic and export markets, and diversifying into other sectors. Both are subject to the overall policy of ethno-economic restructuring and have political connections to high-ranking authorities. The top managers keep direct control of the personnel departments, treating the executives as puppets (in the eyes of the union). The Personnel Managers, being from the same ethnic background as the majority of employees, articulated more employee-oriented opinions (collective cooperation, and human resource management) if not directly criticizing the 
personnel policy of the top management. Finally, both top managements pursued an anti-union policy, perceiving labour primarily as a cost which needed to be rationalized while increasing productivity. With such management policies, conflictual management-labour relations will continue at the enterprise level, preconditioning steady union militancy.

In the case of company B, the state-led management followed a cooperative, collectivist style, based on Japanese management philosophy, Malaysian nationalism and Malay ethic loyalty. However, when a new management took over after years of bad times and the government chose a more business-like policy (liberalization, deregulation, privatization) during the economic crisis of the mid-1980s, things changed at the enterprise level, too. Without meeting the norm of reciprocity and fairness, the union members changed the collaborative leadership for a more militant one. But faced with tough management negotiation and business restructuring, the militant leaders gave up or fell with the closing of two old plants. Meanwhile, the old union strategy of collaboration in a realist perspective returned, but its fate depends on the future policy of the management, the market conditions, and the ability of the union leaders to extract concessions. Moreover the company does not seem to have the same strong market position as the two other companies ( $\mathrm{A}$ and $\mathrm{C}$ ).

In sum, management policy is very important for the policy and practice of enterprise unions. Taking an anti-union, authoritarian attitude to management-labour relations, management can initially form an enterprise union as it prefers, but it cannot keep influencing the union without providing fair deals for the union members in the long term. Sticking to traditional Chinese business conceptions of labour-management relations, the Chinese-owned and managed companies became hotbeds for sustained militancy. A tradition for more collectivist cooperation in state-owned companies is under review by management and higher up in the state, making the operational management more inclined to authoritarian decisionmaking, including rationalization, downsizing and unfair offers to the employees during collective bargaining.

In all companies corporate management is changing, but nowhere is human resource management on the agenda at the top level. Authoritarianism prevails in either individualistic or collectivist 
forms, and this breeds industrial conflicts and militancy. With legally founded structural democracy and independence, Malaysian enterprise unions turn to new leaders and militant methods when the majority of members feel cheated or unfairly treated. Although workers are in-house union members, they compare their lot with the fate of the company and the employees of other similar companies. And although enterprise unions are often operationally dependent unions, they seek support from external union networks and structures in order to improve their strength.

\section{Conclusion}

Having established and refined a legally binding industrial relations system, based on conciliation and compulsory arbitration, the Malaysian government secured a framework for industrial peace and stability from the early 1980s. But industrial peace and stability are not equivalent to industrial harmony and productivity improvements. In order to achieve rapid and qualitatively upgraded industrialization by means of industrial collaboration and productivity improvements, the Malaysian government turned to the Japanese model for management-labour regulation. Within this discourse enterprise unionism became adopted and advocated as a panacea for industrial harmony, providing an in-house perspective for industrial problem-solving between the directly involved partners, generating loyalty, cooperation, productivity and mutual benefits.

The evidence available and the few cases presented falsify this general perception of Malaysian enterprise unionism. Enterprise unions are not by necessity management-dependent, docile and subordinate bodies of worker representation. They are more complex organizations, varying in terms of independence and democracy. In Malaysia, they are legally constituted as structurally independent and democratic organizations, and these properties are explored by workers when managers or enterprise union leaders do not deliver the promised benefits. Authoritarian managements, therefore, sooner or later face more independent and democratic enterprise unions, taking militant action if necessary, although the cultural outlook might still be determined by ethnic identities and norms for fairness (sharing good and bad times). The inter-cultural relationship at the Malaysian enterprises seems to move in a 
direction where the workforce becomes multi-ethnic with a Malay majority while the management will continue to stay with its ethnic business community, be it Malay, Chinese, Indian or various foreign configurations (see Wad 1997a). This scenario provides a very ambiguous picture of class and ethno-cultural structures and dynamics, which interact with the dynamics of the enterprise industrial relations.

The policy of enterprise unionism does not explain why Malaysian industrial relations are very peaceful in terms of strikes. This situation is the outcome of the establishment of a fine-tuned system of conciliation and arbitration which was completed around 1980. However, beneath the calm surface of industrial peace, industrial disharmony prevails in many enterprises, and this may hamper the quest for increased productivity and other industrial improvements.

The policy for enterprise unionism does not seem to be the panacea for industrial harmony in Malaysia, because enterprise unions do not by necessity further industrial harmony either in Malaysia or in other developing societies (Wad 1996a). Enterprise unionism is a more complex phenomenon which is still embedded in misperceptions and misinterpretations - inside Malaysia and outside, among politicians, trade unionists and social scientists as well. The myths of enterprise unionism seem to be a global legacy of Western trade union history.

Peter Wad, Senior Research Fellow, Department of Intercultural Communication and Management (DICM), Copenhagen Business School, Dalgas Have 15, DK-2000 Frederiksberg, Phone dir. (45) 3815 3840, e-mail: pw.sprqk@cbs.dk. Ph.D. in Cultural Sociology from the University of Copenhagen. He has recently completed a research project on enterprise unions and structural change in Malaysia and is presently starting a comparative study on enterprise unions in Malaysia, South Korea and Japan.

\section{REFERENCES}

Balan, S. Nantha (1995) The Relationship between Employer and Employee: Towards Industrial Excellence. Paper to the 8th Law \& Society Seminar, 3 May 1995, Kuala Lumpur.

Benson, J. (1996) 'A Typology of Japanese Enterprise Unions'. British Journal of Industrial Relations. 34 (3): 371-86.
Bhattacherjee, D. (1987) 'Union-Type Effects on Bargaining Outcomes in Indian Manufacturing'. British Journal of Industrial Relations 25 (2): 247-66.

Carrillo, V.J. (1995) 'Flexible Production in the Auto Sector: Industrial Reorganization at Ford-Mexico'. World Development 23(1): 87-101. 
Edgren, G. (1990) 'Employment Adjustment and the Unions: Case Studies of Enterprises in Asia'. International Labour Review 129(5): 629-48.

Jomo, K.S. \& Todd, P. (1994) Trade Unions and the State in Peninsular Malaysia. Kuala Lumpur: Oxford University Press.

Kuala Lumpur Stock Exchange (KLSE) Annual Companies Handbook. Kuala Lumpur: KLSE (selected years).

Latiff Sher Mohamed (1988) In-house Unions - an Operational Strategy. Kuala Lumpur: SMPD Management Consultant Sdn. Bhd.

Means, G.P. (1991) Malaysian Politics. The Second Generation. Singapore: Oxford University Press

Ministry of Human Resources (MHR) (1992) The National Labour Policy. Kuala Lumpur: MHR.

Ministry of Human Resources (MHR) (1995) Trade Unions Act 1959 and Regulations. Kuala Lumpur: MDC Publishers Printers Sdn. Bhd.

- (1996) Industrial Relations Act 1967 (Act 177) \& Rules and Regulations. Kuala Lumpur: International Law Book Services.

Ministry of Labour (1975) Code of Conduct for Industrial Harmony. Kuala Lumpur (mimeo).

Roxborough, I. (1984) Unions and Politics in Mexico. The Case of the Automobile Industry. Cambridge: Cambridge University Press.

Tuman, J.P. (1996) 'Unions and Restructuring in the Mexican Automobile Industry: a Comparative Assessment'. Industrial Relations Journal 27 (4): 317-30.

Wad, P. (1988) "The Japanization of the Malaysian Trade Union Movement', in R. Southhall (ed.) Trade Unions and the New Industrialization of the Third World. London: Zed Books.

- (1996a) Enterprise Unions: From Backward to Vanguard Unionism? CBS Working Paper No. 7, Frederiksberg: Department of Intercultural Commu- nication, Copenhagen Business School.

- (1996b) The Malaysian Policy of Enterprise Unionism and its SocioEconomic Impact. CBS Research Seminar, Autumn (process paper, mimeo).

- (1997a) Business Systems and Industrial Relations in Malaysia: The Restructuring of the Automobile Industry. Occasional Paper No. 14, Frederiksberg: Department of Intercultural Communication and Management, Copenhagen Business School.

- (1997b) Enterprise Unions and Structural Change in Malaysia. Preliminary Research Findings. IKMAS Working Paper (forthcoming 1997).

Wad, P. \& Jomo, K.S. (1994) 'In-house Unions. "Looking East" for Industrial Relations', in K.S. Jomo (ed.) Japan and Malaysian Development. In the Shadow of the Rising Sun. London: Routledge.

Yong, A.K.B. (1996) Malaysian Human Resource Management. Kuala Lumpur: Malaysian Institute of Management.

\section{NOTES}

1 I wish to thank the anonymous referee for comments, the Danish Council for Development Research for financial support, the Economic Planning Unit of the Prime Minister's Department, Malaysia, for a research permit, and the DICM and the Institute of Advanced Studies, University of Malaya, for institutional backup. My gratitude applies especially to trade unionists, managers and public servants who made the research possible, although the ultimate responsibility for the conclusions rests with the author. 